corners and has slipped into errors which confuse. Few geneticists for example, would feel happy with the sentence: 'The genes occupying identical loci on homologous chromosomes also are homologous' (pp 9/10). This could well confuse the novice when he or she comes to grips with dominant and recessive inheritance and with homozygosity or heterozygosity. A criticism relevant to those readers outside the USA is that most of the legislation discussed (of patents, commercial law, state law etc) is relevant only in the USA.

Now I should come clean! A feeling that confronts me each time I dip into this book is that Professor Holtzman is telling us what should be done, not providing us with facts and a balanced discussion. In my view this is the major issue in medical genetics and ethics today. Everyone should be open about those matters which are within the individual's freedom of choice and that choice should be clear. Legal frameworks do give room for personal choice; those who survey the field have a responsibility to emphasise that fact. I would agree with and give high importance to many of Professor Holtzman's opinions. However, the barrage of his opinions - all mixed-up with the facts - means that the lay reader might be too punch-drunk to disagree!

I agree very much with the need for adequate provision of genetic counselling services ( $p$ 157). In the USA the medical care systems may well encourage diagnostic and laboratory facilities to be made available at the expense of those involving genetic counselling. Perhaps Holtzman envisages a more directive genetic counselling approach than would most geneticists.

In conclusion, Holtzman offers his own recommendations. These emphasise the inevitability of genetic screening, notwithstanding its dangers. Holtzman rightly stresses the need for community knowledge to be increased and for rigorous quality control.

What advice would I give to those who are involved in or interested in the ethics of genetic screening? Buy the paperback version. Do not read it through and through; use it as a source of information. Do not assume that Holtzman's conclusions must be agreed with; use them to provoke your own thoughts and ideas. Above all read other publications which impinge on this important topic for example: Wald $\mathrm{N}$, ed. Antenatal and Neonatal Screening. Oxford, Oxford University Press, 1984;
Warnock M. A Question of Life. Oxford, Basil Blackwell Ltd, 1985, and Church of Scotland. Abortion in Debate. Edinburgh, Quorum Press, 1987.

In fairness to Professor Holtzman, I am sure that such scepticism is exactly the response that he wishes.

SANDY RAEBURN, Professor of Clinical Genetics, Interdisciplinary Centre for Medical Genetics, City Hospital, Hucknall Road, Nottingham NG5 IPB.

\section{By What Right?: Studies in Medicine, Ethics and the Law}

Edited by Peter de Cruz and David

McNaughton, 73 pages, Newcastleunder-Lyme, $£ 7.00$, Penrhos

Publications, 1989

This book is the outcome of a weekend conference held in 1987 to mark the launching of a one-year part-time Diploma in Medical Ethics, which is offered by the Departments of Law and Philosophy at the University of Keele. All but one of the essays are revised versions of papers delivered at the conference. It is therefore to be expected that the contents of the book do not contribute to a single theme. There are five essays: The Leonard Arthur case by Peter de Cruz (doctor); Killing and letting die by David McNaughton (philosopher); Construction and working of a district hospital ethics committee by Christopher Rice (clinical lecturer); Human experimentation by Calliope Farsides (philosopher); The ethics of infertility treatment and embryo research by David Jabbari (lawyer). The essays all make interesting contributions individually, and no doubt it was a good conference. It is less obvious that the essays cohere as a unified book.

\section{R S DOWNIE,}

Professor of Moral Philosophy, Glasgow University.

\section{Undergraduate Medical Ethics Education}

F Baylis and J Downie, 142 pages, London, Ontario, Canada, \$8.95, Westminster Institute for Ethics and
Human Values, 1990

This book provides a useful survey of medical ethics education in the sixteen Canadian medical schools, and complements studies done in Britain, the United States and other countries. The survey was carried out in 1989 by the use of a wide-ranging questionnaire sent to each medical school.

Information was sought on the amount of ethics teaching, the curriculum and content, the stages in the undergraduate course that teaching took place, and the methods of teaching. This book summarises and tabulates the responses, and there emerges a mixed picture with some ethics being formally taught in all but one of the schools, but wide variation in both methods of teaching, curriculum time and content. Where ethics is taught there is also formal student evaluation, but methods of evaluation are equally diverse.

In conclusion, the study specifically reinforces many of the recommendations of the British Pond Report (1), emphasising the importance of ethics in health-care practice and pointing out the need for well-planned ethics teaching throughout the undergraduate course. Also needed is further training in medical ethics for many teachers, and multi-disciplinary co-operation in planning and carrying out the teaching.

This book will provide information on the various approaches that are being adopted in Canada, for those who are involved in teaching health care ethics to medical students. At a stage where the subject is developing rapidly this is a useful summary of the current position.

\section{Reference}

(1) Boyd K, ed. Report of a working party on the teaching of medical ethics: the Pond Report. London: IME Publications Ltd, 1987.

PROFESSOR RICHARD WEST, Medical Postgraduate Department, University of Bristol, Canynge Hall, Whiteladies Road, Bristol BS8 2PR.

\section{Birthrights: Law and Ethics at the Beginnings of Life}

Edited by Robert Lee and Derek Morgan, 222 pages, London, £9.99, Routledge, 1990 